\title{
БIОАОГIЧНА БЕЗПЕКА
}

UDC 504.06:577.4

DOI https://doi.org/10.32846/2306-9716-2019-2-25-17

\section{RESEARCHING THE IMPACT OF OPTICAL RADIATION AND ILLUMINATION FOR PRODUCTION PERSONNEL}

\author{
Savchenko L., Savchenko V. \\ Zhytomyr National Agroecological University \\ Staryi Blvd, 7, 10008, Zhytomyr \\ slgua@ukr.net,dgs-ua@ukr.net
}

\begin{abstract}
The article describes the essence of various lighting systems, considers the organization of lighting in the study area, the influence of lighting conditions and spectra of optical radiation on the degree of visual fatigue, which arises when performing high-intensity visual work is determined. Key words: optical radiation, illumination, visual fatigue, achromatic adisapropy, observation objects, optical properties, illumination of the working surface, angular size.
\end{abstract}

Дослідження впливу спектрів оптичного випромінювання та освітленості на виробничий персонал. Савченко Л.Г., Савченко В.М. У статті розкрито сутність різноманітних систем освітлення, розглядається організація освітлення в досліджуваному приміщенні, визначено вплив умов освітлення та спектрів оптичного випромінювання на ступінь зорового стомлення, що виникає під час виконання зорових робіт високої складності. Ключові слова: оптичне випромінювання, освітленість, зорове стомлення, ахроматична адиспаропія, об'єкти спостереження, оптичні властивості, освітленість робочої поверхні, кутовий розмір

Исследование влияния спектров оптического излучения и освещенности на производственный персонал. Савченко Л.Г., Савченко В.Н. В статье раскрыта сущность различных систем освещения, рассматривается организация освещения в исследуемом помещении, определено влияние условий освещения и спектров оптического излучения на степень зрительного утомления, возникающего при выполнении зрительных работ высокой сложности. Ключевые слова: оптическое излучение, освещенность, зрительное утомление, ахроматическая адиспаропия, объекты наблюдения, оптические свойства, освещенность рабочей поверхности, угловой размер.

Establishing the issue. The development of more powerful and efficient LEDs and their use in lighting systems continues to be one of the most important areas of modern lighting engineering. Evidence for this is the growing number of companies working in this field, the continuous growth of publications, patents, conferences on this topic and, most importantly, the rapid increase in the production of super-powerful and efficient lamps, which gain widespread applications: automotive, architectural and decorative illumination, general lighting of residential and industrial premises, etc.

Analysis of recent researches. Analysis of the material accumulated in recent years and relating to the reaction of the human sight to various conditions of artificial lighting can conclude that virtually no information is given that give a physiological and hygienic evaluation of the influence of lamps used for indoor lighting.

The purpose of the research is to evaluate the influence of optical radiation spectra and illumination on production personnel.

Main material. The conditions of artificial lighting in industrial companies have a significant effect on visual work, physical and nervous and psychological condition of people, and, consequently, on productivity, quality of production and level of occupational injuries. The more precise and tense the performed visual work, the greater this effect. Numerous studies have determined the dependence of visual functions on conditions of artificial lighting. They are guided by the standardization of quantitative and qualitative characteristics of industrial lighting installations and in developing recommendations for the choice of sources of light, systems and methods of artificial lighting.

Today, there are a large number of different lighting systems that differ from each other, the principle of functioning, purpose, technical characteristics and efficiency. Below we provide brief description of the most common lighting systems.

In the incandescent lamps, the effect of heating the conductor (the body of ignition) is used when the electric current flows through it (the thermal action of the current). The temperature of the body burns sharply after the current is turned on. The heat of the body emits electromagnetic thermal radiation in accordance with 
Planck's law. Planck's function has a maximum, whose position on the scale of wavelengths depends on temperature. This maximum moves with increasing temperature towards the smaller wavelengths (Wien's displacement law). To obtain visible radiation, it is necessary that the temperature is in the order of several thousand degrees. The fewer the temperature, the smaller the proportion of visible light and the more radiated radiation appears. The glass bulb, filled with inert gas, prevents the rapid destruction of the body of ignition due to the oxidation of oxygen air [3, p. 55]. In most of the incandescent lamps are intended for general, local and decorative lighting purposes. The efficiency of the incandescent lamps depends on the temperature of the helix heat and varies, usually within $5-15 \%$. As the temperature rises, the efficiency of the lamps increases, but its longevity is greatly reduced. When the voltage increases, the brightness increases, but at the same time, the service life of the lamp decreases by $95 \%$ [4, p. 16].

Discharge lamps are characterized by long service life and high nominal efficiency and the need for additional electronic devices to stabilize them at work. The gas filling the gas-discharge lamp must be ionized under the action of an electrical voltage in order to obtain the necessary electrical conductivity. As a rule, a gas discharge lamp is required to run higher voltage than to support discharge. For this purpose, special starters or other ignition devices are used. In addition, for normal operation of the lamp, a ballast load is required, which ensures the stability of the electrical characteristics of the lamp. The starter, in conjunction with the ballast, forms start-up devices. The discharge temperature can reach over a thousand degrees Kelvin $\left(800-900^{\circ} \mathrm{C}\right)$ [6].

Specific types of gas-discharge lamps are often referred to as gas used in them - neon, argon, xenon, krypton, sodium, mercury and metal halide. The most common are fluorescent lamps; metal halide lamps; sodium high and low pressure lamps.

For general searchlight lighting of open spaces with low level of illumination, the most effective light sources are metal halide and sodium high pressure lamps. They are one of the most economical sources of light for outdoor lighting systems and are used to illuminate streets, squares, parking lots, tunnels and high industrial premises. Widespread use in outdoor lighting of public buildings, in local lighting jobs, in light advertising and illuminating the facades of buildings found effective compact fluorescent lamps.

The sulfur lamp is a high-performance illuminator of a full spectrum without electrodes, in which the light source is a sulfur plasma heated by microwave radiation in an atmosphere of inert gas. A sulfur plasma emits a powerful light in a spectrum close to sunlight, almost without ultraviolet light. Sulfur lamps are used to illuminate large areas, interiors of underground and underground stations and buildings, military, medical, railway, and others, where there is a limit on the daily interval of time [7].
LED bulb is a semiconductor device with electron-hole transition or metal-semiconductor contact, which creates optical radiation when passing through the electric current. LED lighting technologies have been widely used in fixtures, spotlights, LED strips, and especially in compact lighting fixtures (for example, flashlights) thanks to their efficient power consumption and ease of construction. LED lights are divided into street and interiors. Currently, they are used to illuminate buildings, cars, streets and advertising structures, fountains, tunnels and bridges. This lighting is used to illuminate industrial and office premises, home furnishings and furniture.

We will conduct a study of the effect of illumination on production personnel on an example of work of IT department. The dimensions of the premises where the IT department is: length $7 \mathrm{~m}$, width $5,5 \mathrm{~m}$, height $3 \mathrm{~m}$. The total area is $38,5 \mathrm{SQM}$. There are 3 employees in the room, that is, for each one there is 38,5 SQM, which corresponds to sanitary norms (not less than 20 SQM).

Inside the study room, side lighting and artificial lighting are applied. Natural light is normalized by the natural light intensity rate (NLI). This rate is calculated according to the formula [1] and is equal to the ratio of natural light inside the room to the simultaneous measurement of external illumination. The value of the NLI depends on the size of the windows and the removal of the calculated point from them. The target value of NLI for this room is determined by the characteristics: the system of natural light, the purpose of the room, the light climate belt. In our case: with side lighting, $\mathrm{e}_{\min }=$ $(1,5) \%$, light zone IV. The orientation of the light cavities is Northern. The building in which this room is located is located in the IV zone of light climate (СниП II-4-79), therefore, the minimum value of natural lighting intensity rate (NLI) is normed $E_{n}{ }^{I V}=1,5 \%$.

In premises with computers except for the work with computers where works with books is planned, it is necessary to foresee the following:

- natural light in the room is presented in the form of one-sided lighting;

- there is a light slit with an area of 8,96 SQM in the room;

- light slits are periodically cleaned of pollution (2 times a month);

- light slits have opening parts (transoms);

- the orientation of the light slits - the southern.

The calculation of natural light is reduced to the selection of light cavities in such a way that the actual NLI and the NLI normative differed no more than $10 \%$.

1. Choice of normative coefficient.

2. Estimated size of light cubes in the room.

3 . The calculation of total area of light transmittance coefficient

Thus, natural light meets the requirements [3], such as:

$$
S_{\text {fac }}=7,96 \mathrm{SQM} \text { and } S_{\text {cal }}=7,41 \mathrm{SQM} \text {, therefore } S_{\text {fac }}>S_{\text {cal }}
$$


Lighting of the workplaces of specialists of the department

\begin{tabular}{|c|c|c|c|}
\hline & Index & Factual & Norm \\
\hline \multirow{4}{*}{$\underset{\mathfrak{N} \text { Computer room } 1}{ }$} & Lighting of the workplace, E, lux. & 200 & 300 \\
\hline & Category (accuracy) of visual works, Zor. & $\mathrm{C}$ & A \\
\hline & Duration of concentrated observation, $\%$. & 120 & 24 \\
\hline & Number of important observation objects, units. & 5 & 4 \\
\hline \multirow{4}{*}{$\begin{array}{c}\text { Computer room } \\
№ ~\end{array}$} & Lighting of the workplace, E, lux. & 150 & 300 \\
\hline & Category (accuracy) of visual works, Zor. & $\mathrm{D}$ & A \\
\hline & Duration of concentrated observation, $\%$. & 5 & 5 \\
\hline & Number of important observation objects, units. & 3 & 3 \\
\hline \multirow{4}{*}{ 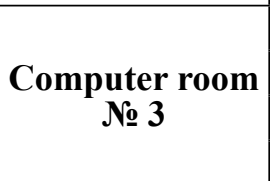 } & Lighting of the workplace, E, lux. & 300 & 300 \\
\hline & Category (accuracy) of visual works, Zor. & A & A \\
\hline & Duration of concentrated observation, $\%$. & 50 & 25 \\
\hline & Number of important observation object, units. & 8 & 5 \\
\hline
\end{tabular}

and we can conclude that in natural light, visual conditions meet the regulatory requirements. Consequently, the room under study meets all requirements in accordance with the NLI regulations.

Artificial lighting in premises of computer operation is carried out by a system of uniform illumination. In administrative and public spaces, in cases of overwhelming work with documents, the use of the combined lighting system is allowed (in addition to the general lighting, local lighting fixtures are designed to illuminate the location of documents).

The general illumination is executed in the form of intermittent lines of fixtures, located above the desk, closer to its front edge, addressed to the operator.

The light source in the room is fluorescent lamps, the height of the suspension lamps is $2,9 \mathrm{~m}$, the distance between the lamps is $1 \mathrm{~m}$. Data on the illumination of each workplace are given in Table1.

Therefore, an additional lamp must be installed over the second and first jobs.

To illuminate the working surface, use a light instrument located directly above the object of observation. As a source of local lighting, light-emitting diodes of high intensity type U-337 are used. The level of illumination $(E)$, which is created on the working surface, is regulated by the voltage of the power supply and varies in the range from 100 to 1000 lux.

Metal objects with angular dimensions $\alpha=1$, and $\alpha=5$ ' belonging to the I and III grades, respectively, were used as objects of observation with directional-diffused reflection. As diffuse objects, Landolt rings were used with angular dimensions

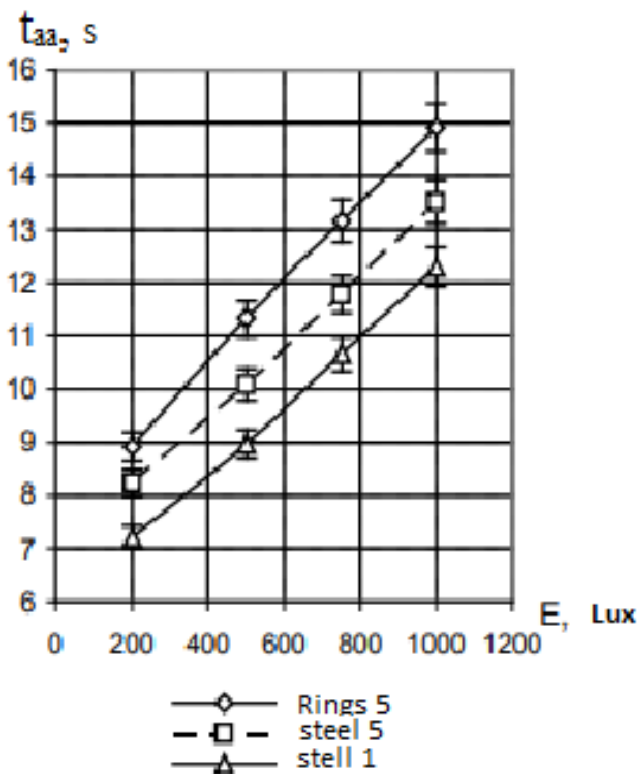

Achromatic adisapropy

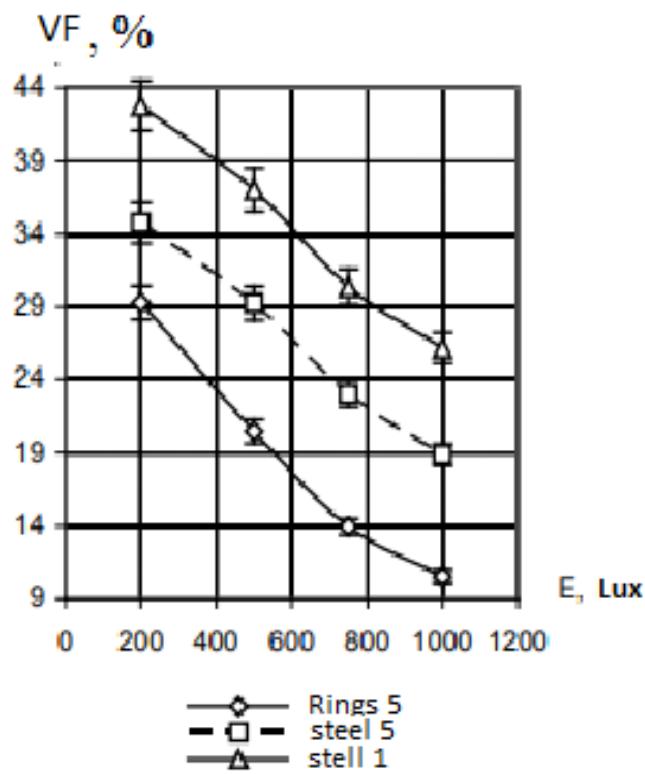

Visual fatigue (VF)

Fig. 1. Dependence of $t_{a a}$ and Visual Fatigue on the level of lighting 
$\alpha=5$ ' and negative contrast of the object with the background.

In the course of conducting experimental research, the dependence of $t_{a a}$ on the duration of visual work was established upon changing the level of illumination of the working surface. The experiment was carried out as follows: after a preliminary adaptation for 15 minutes, the test, stabilizing the line of sight by means of a fixing point, observes the boundary of the section of adjacent fields. The moments of the beginning of observation and the visual balance of the brightness of adjacent fields the time of achromatic adisapropy (ta), was fixed by a stopwatch [2]. Absolute value of $t_{a a}$ was measured before the sight work $\left(\mathrm{t}_{\mathrm{ai}}\right)$ and after it $\left(\mathrm{t}_{\mathrm{aj}}\right)$. The visual fatigue index was calculated after two hours of visual load:

$$
\mathrm{A}=\left(1-\frac{t_{a j}}{t_{a i}}\right) * 100 \% \text {, }
$$

where $t_{a i}$ - time of achromatic adisapropy before the beginning of visual work, $s$; $\mathrm{t}_{\mathrm{aj}}$ - time of achromatic adisapropy after the visual work, $\mathrm{s}$.

As per results obtained, we built charts of correlation of $t_{a a}=f(E)$ and $3 \mathrm{C}=\mathrm{f}(\mathrm{E})$ (fig. 1).The charts show that with a change in the degree of complexity of the visual task $\mathrm{t}_{\mathrm{aa}}$ for $\alpha=5$ ' it is $9,9 \div 19,4 \%$ higher than with $\alpha=1$ ' (for directional-reflective objects) and 8,38 $\div$ $12,4 \%$ lower than at $\alpha=5$ ' (for diffuse objects) throughout the studied range of illumination. In addition, when working with $\alpha=5$ ' (diffuse objects), the AS is in the range from 10,56 to $29,32 \%$, with $\alpha=1$ ' (directed-r eflective objects) in the range from 26,21 to $42.79 \%$, with $\alpha=5$ ' its limits make up from 18,89 to $34,78 \%$.

The analysis of the results of the influence of the degree of complexity of the visual load on the fatigue of the organ of vision indicates that the indicator of visual fatigue is the higher, the smaller the angular size of the object of differentiation. The least visual fatigue is observed in the range from 750 to 1000 lux, depending on the degree of complexity of the visual load.

Conclusions. Thus, the lighting should provide the necessary spectral composition of light for the correct transmission of light. The correct light transmission is created by natural light and artificial light sources with a spectral characteristic close to natural light. The results obtained in the course of the research can be used in the development of lighting standards and requirements for the quality of the light environment, as well as in the design of lighting installations with LEDs as the most promising from the energy point of view, light sources.

\section{References}

1. Зеркалов Д.В. Охорона праці в галузі: загальні вимоги : навчальний посібник. Київ : Основа, 2011. 551 c. URL: http://www. zerkalov.kiev.ua/sites/default/files/opgkniga_0.pdf.

2. Абрамова Л.В., Михайлова, Е.М. Определение оптимальных условий освещения объектов светодиодными установками. Известия вузов. Проблемы энергетики. 2012. № № 1-2. С. 102-106.

3. Освітлення промислових об’єктів : навчальний посібник / П.П. Говоров та ін. Тернопіль : Джура, 2008. 388 с.

4. Гоман В.В., Тарасов Ф.Е. Проектирование и расчет систем искусственного освещения : учебное пособие. Екатеринбург : УрФУ, 2013. $76 \mathrm{c}$.

5. ДБН В.2.5-28:2006 «Природне і штучне освітлення». Чинний із 1 жовтня 2006 p. URL: http://dbn.at.ua/load/1-1-0-394 (дата звернення: 19.03.2019).

6. Commission Regulation (EC) № 244/2009 of 18 March 2009 implementing Directive 2005/32/EC of the European Parliament and of the Council with regard to ecodesign requirements for non-directional household lamps Text with EEA relevance. URL: http://eur-lex.europa.eu/LexUriServ/LexUriServ.do?uri=OJ:L:2009:076:0003:01:EN:HTM (дата звернення: 19.03.2019).

7. Energies parende LED-Lampen. URL: http://www.test.de/haushaltgarten/tests/Energiesparende-LED-Lampen-Sie-holenauf-1816330-1823439/ (дата звернення: 19.03.2019). 